\title{
Suffering in the Sociology of Zygmunt Bauman
}

\author{
Michael Hviid Jacobsen ${ }^{1}$ \\ ${ }^{1}$ Department of Sociology and Social Work, Aalborg University, Fibigerstrcede 13, office no. 75, 9220 \\ Aalborg Øst, Denmark
}

$\mathbf{T}_{\text {he topic of human suffering loomed large throughout the writings of Zygmunt Bauman. If anything, his work }}$ can be characterized as a 'sociology of suffering'. From the early writings until his very last, suffering constituted a key concern in Bauman's description of the transformation of society from a solid-modern to a liquid-modern outlook. In his work, there are certain shifts in who and what he regards as the embodiments or expressions of suffering, and there is thus a keen eye on the changing landscape of suffering, its causes and consequences, from past to present. But there is nevertheless always a continuous and vehement defence for those living at the outskirts or at the bottom of society. The article will also explore what Bauman suggest should be done about the presence of suffering, and the article will briefly discuss the viability of his ideas on a morality of proximity as a way to alleviate suffering.

Keywords: Keywords: Zygmunt Bauman, sociology of suffering, solid-modern suffering, liquid-modern suffering, solidarity, morality

\section{Introduction}

Suffering makes the world go around. Although this may sound as an excessively gloomy and cynical observation, all societies throughout human history have produced and perpetuated human suffering either through elaborate and determined measures or through the neglect of those who in one way or other have fallen below the level of human decency and outside our realm of concern and care. Think of wars, famines, natural disasters, killings, ethnic cleansings, genocides, persecutions, stigmatizations, marginalization's and so on. The outcome has always been human suffering in some shape or form. Suffering is thus an integral part of the human condition - in the past as well as in the present. Some of the causes of this suffering are beyond human control or stem from non-human forces, whereas other causes are the direct or indirect outcome of human action or social forces. 
The theme of suffering has always attracted the attention of thinkers, poets, politicians and social commentators. From theologians and moral philosophers to psychologists and sociologists, suffering has constituted a recurrent topic in the analysis of human and social life. One of the most prominent contemporary observers of the human condition was Polish-English sociologist Zygmunt Bauman. For more than half a century, he practiced the discipline and heeded the calling of sociology. Throughout the years, he has at an almost inhuman pace published numerous pieces of work that have left a lasting and indelible imprint on future studies of a variety of sociological topics such as, most prominently, the Holocaust, morality, postmodernity, utopia, culture, the intellectuals, critical sociology, liquid modernity, globalization, identity, fear, inequality, ethics, education, community, love, individualization, education, freedom, consumerism, surveillance, religion, nostalgia, etc. In his writing, Bauman regarded the practice of sociology as a hermeneutic enterprise in which the sociologist in the role of 'interpreter' should decipher the unfolding of human life and translate and mediate this knowledge back to society, thus allowing the members of society to act on this new knowledge (Bauman, 1978, 1987). In his own words, sociology is an 'ongoing conversation with human experience' (Bauman, 1992:213), and it is this human life experience that has continued to animate and to constitute the core of his curiosity. There is, however, also an unmistakable critical dimension to Bauman's interpretative work - a gnawing dissatisfaction with the way the world is currently working, a relentless critique of the seemingly unchangeable character of the way life is lived and a valiant defence of the possibility of creating a better world (Bauman, 1976a, 1976b). Throughout his comprehensive body of work, Bauman set out to criticize the perpetuation and continuation of suffering in all its shapes and forms no matter what specific topic he was writing on, and in this way he may meaningfully be characterized as a 'sociologist of suffering' par excellence.

In this article, we shall revisit and review the work of Zygmunt Bauman in order to excavate some of his main ideas on suffering or what will here be framed under the notion of 'social suffering'. In all of Bauman's books - no matter their specific topic - suffering has always been a prevalent concern whether explicitly stated or more implicitly hidden between the lines. First, we shall look into how we may understand social suffering as a human and social emotion. Following this, we will dig into Bauman's oeuvre in order to detect the changing role of suffering has played in his writings. This leads us into a delineation of how suffering according to Bauman is experienced during solid-modern times in the shape of, for example, totalitarianism and genocide. before we turn to how social suffering in his view is experienced and expressed 
during liquid-modern times. This leads to the final section in which we will present and discuss of Bauman's suggestions for how suffering may be alleviated.

\section{Suffering as emotion}

Suffering is an integral part of our being-in-the world. Very few people pass through life without experiencing suffering at some point or other. In this way, suffering is something most can relate to. Still, however, it is difficult to define suffering in a simple one-liner, the reason being that suffering is a multi-facetted phenomenon. Fundamentally, suffering is the experience of undergoing pain or hardship, whether physiological, psychological or otherwise, and whether directly felt or derived from other types of experience. It is often - however not exclusively the outcome of externally imposed or inflicted harm, resulting in inner feelings of pain, deprivation or distress. Due to its multi-facetted nature, suffering can be studied from many different perspectives, each with their own specialized vernacular and frames of understanding: medicine, theology, psychology, sociology and so on. Often scientific studies of suffering differentiate between physical suffering (frequently described as 'pain') on the one hand, and suffering as a social experience connected to structural, cultural or relational aspects of life, on the other (sometimes called 'social suffering'). Whereas 'pain' often evokes a physical imagery of harm inflicted directly on the human body, suffering as a social experience is much more of an undefinable and slippery phenomenon, difficult do describe by reference to bodily pain. Suffering can thus be concrete (like the pain associated, for example, with physical assault or somatic disease) or it can be less tangible and more abstract (such as, for example, the experience of Weltschmerz or the outcome of social deprivation).

Ludwig Wittgenstein once insisted that 'no torment can be greater than what a single human being may suffer ... The whole planet can suffer no greater torment than a single soul' (Wittgenstein cited in Bauman, 2001a:210). Despite its sympathetic message, the veracity or validity of this statement is obviously difficult to determine, as experiences of suffering are almost impossible to measure and compare. There is, however, no doubt that suffering is experienced both at the individual and at the collective level. Suffering is simultaneously a generalized and an individualized experience - something that happens to many people (sometimes at the same time and for the same reasons), but also something that afflicts actual and concrete individuals (and some more than others). The proportion of suffering in the world is thus not equally distributed, and like most other unequally distributed phenomena, those at the bottom of society often carry a heavier burden of suffering than those at the top (see, e.g., Bourdieu et 
al., 1999). Suffering is thus not only an experience suffered by the individual in isolation, but something that affects larger groups of people (sometimes even cross-generationally), which is why it is an important topic for scholars working within a field such as sociology concerned as it is with 'the social'. As already C. Wright Mills (1959) famously informed his readers, the 'sociological imagination' consists of connecting what at the outset may seem to be merely private or individual experiences with the larger structural and social conditions under which they occur.

Often suffering is regarded as the existential or phenomenological experience of being human in the world, something being born with us from the very beginning. In this way, suffering is surrounded by some innocence - it is almost unavoidable - and thus to be human is to suffer. However, in recent years, there has been an increased concern with notions of 'social harm' and 'social suffering' (see, e.g., Pemberton, 2016; Wilkinson, 2004, 2005), both concepts stressing the social nature and causes of harm/suffering. 'Social suffering' can be defined as 'collective and individual human suffering associated with life conditions shaped by powerful social forces'. Moreover, according to Arthur Kleinman, Veena Das and Margaret Lock (1996: xi), social suffering 'results from what political, economic and institutional power does to people, and, reciprocally, how these forms of power themselves responses to social problems'. There is a dual-process involved here - that suffering is created or inflicted by institutions and agencies and that they again respond to how such suffering is to be managed. There thus seems to be a circular process in social suffering: that suffering is socially produced and then again socially reproduced by the way suffering is approached and handled. That suffering is 'social' also entails that suffering is not natural, and thus not something to be passively observed and accepted. Suffering can thus be countered, objected to, diminished and prevented if active engagement with the roots of suffering is pursued (Jacobsen, 2020). This objective has also been a main motivational force behind many political and social movements throughout history.

Suffering is therefore, in its many different shapes and forms, a social experience. Perhaps most importantly, suffering or social suffering is an emotional experience - it is an emotion. Suffering is something that people feel not just something they think - it influences the mind and body of the sufferer in a qualitatively different manner than other emotions. In recent years, the 'sociology of emotions' has risen to prominence as a sub-discipline devoted to the study of emotions within different social contexts (see, e.g., Bericat, 2016). However, suffering has often been neglected as an emotion deserving of attention within this line of research, perhaps being regarded as too intangible and philosophically abstract to investigate. Looking through most encyclopaedias or handbooks of 'the sociology of emotions', suffering is hardly ever mentioned 
and there is no separate entry devoted to a definition of suffering as an emotion. This is quite surprising, because suffering is - after all - an emotion alongside so many other emotions studied by sociologists such as trust, loyalty, shame, pride, embarrassment, love, hate, contempt, remorse and so on. Yet suffering is still conspicuous by its absence. But why is this the case? There are many possible reasons, but perhaps the most obvious is simply that suffering is mostly not regarded as 'an emotion' or 'a feeling'. It seems more abstract than these other emotions and true, it does lack several of the characteristics of an 'emotion' as specified by Arlie R. Hochschild (1990). Despite this, there is little doubt the suffering is indeed something that people feel. Contrary to many other emotions - in emotions research particularly the so-called 'primary emotions' such as fear, happiness, sadness or anger- suffering does not have a definitive physiological reaction or bodily expression. It may thus be difficult to see or document that people in fact suffer, because many suffer invisibly and in silence. Suffering may be seen or unseen, excruciatingly painful or less so, lasting or fleeting, and so on. Social suffering is the often invisible emotional response to inhumane and indecent treatment of humans against each other. Sometimes there is no identifiable instigator or perpetrator of suffering (structural forces and symbolic violence are widely known to be difficult to observe directly), but at other times specific groups or individuals are responsible for inflicting pain and suffering.

\section{A world of suffering}

Zygmunt Bauman is conventionally not regarded as an obvious contributor to the particular sub-discipline of 'the sociology of emotions', although his work does in fact contain frequent references to and analyses of a number of emotions such as love, fear, freedom, nostalgia, ambivalence and suffering. The interesting thing about Bauman's work is that he seems to treat emotions in a rather unemotional manner. By this is meant that he does not dig deep into how it actually feels for people to experience their emotions, but he rather sees these emotions as something being socially produced and reproduced (and not least distorted) through various processes and by different agencies (Jacobsen, 2019). Bauman is thus not an archetypal sociologist of emotions, he is more a general social theorist, and he thus not so much presents a phenomenology of suffering, explicating and detailing what suffering feels like, but more of a critical perspective on the structural causes and human consequences of social suffering.

Anyone who has read Bauman's books will know that they ooze of suffering - suffering has been there from the beginning to the end. Hence, it is unsurprising that there has been a certain academic interest in Bauman's perspective on suffering (see, e.g., Best, 2016; Jacobsen 
and Marshman 2008; Wilkinson, 2007). His sociology can best be described as a critical and humanistic enterprise, always focusing on the relentless impact of social forces on human life, and asking his readers - mostly an academic audience - to accept their responsibility for making the causes and consequences of suffering known to the world (Tester, 2004). As Dennis Smith once observed: 'The driving force behind Zygmunt Bauman's work as a sociologist has been two things: first, a sense of intellectual and moral outrage about the extent to which societies are run on the basis of untruth and self-deception; and, second, a deep dissatisfaction with the evil and suffering this makes possible' (Smith, 1998:40).

Suffering thus remained one of the key topics running throughout Bauman's extensive writings, often closely connected to a concern with understanding how culture changes and shapes experiences of suffering. As Bauman once remarked in an interview when asked to look back upon his own previous contributions there 'were actually two things with which I was concerned throughout my writings, throughout my academic career. One was the working class, standing for the downtrodden or the underdog, for suffering in general. For a long time there was a sign of identity between the two: the working class as the embodiment of suffering. That was one topic, and the other was culture... To understand how the visibility, tangibility and power of reality - and the conviction concerning the belief in reality - are being constructed: that is why I became interested in culture' (Bauman, 1992:206). Suffering and culture thus constitute the core of Bauman's body of work. Throughout his work, Bauman remained a champion of the weak, the poor, the marginalized and those who are treated inhumanely. His specific focus on suffering, however, changed over the years. In his books one will therefore find many different depictions of man's inhumanity towards man whether as part of the class-based oppression in capitalist society, in the concentration camps of World War II or as part of contemporary neoliberal politics (see, e.g. Bauman, 1982, 1989, 2011). Sometimes this suffering has an identifiable social sender, at other times seemingly more anonymous and amorphous social forces seem to be at work such as globalization and individualization. There are thus many specific as well as general faces of suffering appearing throughout Bauman's work: the working class in capitalist society, the Jews in concentration camps, strangers, refugees, the 'underclass', the 'new poor' and 'flawed consumers' and all the 'vagabonds' and the human 'waste' of contemporary liquid-modern life (Jacobsen and Marshman, 2008). However, particularly the persistence of economic poverty, social inequality and the inability to uphold a decent human life spurred his sociological and moral indignation (see, e.g., Bauman, 2011, 2013). He even denoted poverty the 'meta-humiliation' that in turn serves as a 'trampoline' for other humiliations and indignities in life (Bauman and Tester, 2001:154). Hence all of Bauman's books ooze with 
solidarity and sympathy for people caught and suspended in the webs of power, oppression, persecution, poverty and potential extermination. He thus claimed that we, in the last instance, can only judge the moral character of 'society by the care it takes of its weakest members' (Bauman, 1990:23).

Like all other emotions, it is - at least in my view - pointless to try to quantify suffering. Suffering is for all practical intents and purposes a qualitative experience whose depths and dimensions - human and social - are complex, thus making them difficult to capture or measure through surveys or statistics (even though many within positivist or behaviourist paradigms attempt to do so). Even though some scholars have excelled in quantifying and measuring levels of, for example, happiness, fear or grief, it often seems unconvincing when 'levels of happiness' between different countries are compared or when 'scales of fear' are used to analyse the fluctuating level of fear in individuals or societies. In Bauman's writings suffering is primarily presented as a qualitative phenomenon - something that has depths, processes, directions, density, and the like. Moreover, his treatment of the topic of suffering is almost exclusively conceptual and theoretical as he has not carried out empirical studies of suffering. In his work, we see the different faces of suffering through conceptual development, case stories from news reports and insights from existing research. Although Bauman cites reports for example from the WHO or OECD about the state of global poverty, the unequal distribution of the wealth of the world or the total number of refugees in the world (see, e.g., Bauman, 2004:78-79; 2013:6$7 ; 2016: 7)$, his descriptions of suffering are always, in one way or other, concerned with showing how suffering is brought about by social conditions and how it has serious human consequences. Some of the suffering analysed by Bauman is what might be called 'spectacular suffering' such as ground-breaking historical events like the Holocaust with its millions of human casualties (Bauman, 1989). However, most of the suffering described by him is rather 'silent suffering' - the suffering that largely goes unnoticed and which does not attract headlines or changes historical consciousness or development. This is the kind of suffering experienced by individuals and groups in society unable to raise their voices, to demand assistance or crave relief. Let us look a bit more into this world of suffering described by Bauman.

\section{Solid-modern suffering}

Particularly throughout the 1980s, Bauman established himself as a staunch critic of modern society with what he regarded as its obsessive drive for order. In books such as Legislators and Interpreters (1987), Freedom (1988), Modernity and the Holocaust (1989) and Modernity and 
Ambivalence (1991a), he provided an in-depth analysis of some of the (in)human consequences of the dark side of modernity. Although modernity and modern society is often associated with positive developments such as progress, liberation and rising levels of prosperity, Bauman - in a manner true to critical social theory - almost one-sidedly concentrates on the negative aspects of modern society (Carleheden, 2008). As he once observed: 'Modernity was a long march to prison. It never arrived there (though in some places, like Stalin's Russia, Hitler's Germany, or Mao's China, it came quite close), albeit not for lack of trying' (Bauman, 1992:xvii). In Bauman's work, modernity is thus depicted as a period in which order, reason, unfreedom and repression become 'normalized'. Moreover, he also shows how modernity waged a war against difference, diversity and ambivalence in its quest for order (Bauman, 1991a), and that this obsessive urge - pursued through a number of general strategies by Bauman sometimes called 'social engineering' or 'gardening' - to force order on an innately unorderly world came with high human costs.

It is in Bauman's award-winning book Modernity and the Holocaust (1989) that this perspective was elaborated and exemplified with special reference to the persecution and genocide of the European Jews during World War II. Like many European Jews from assimilated families at that time, Bauman's first wife Janina had experienced her Jewishness in the light of the Holocaust, and her memoirs Winter in the Morning deals with her teenage-years in the Warsaw ghetto and the uncertain and insecure periods of hiding from the Nazis. In 1944, while still in hiding and continually in fear for her life, Janina experienced something of an epiphany regarding her sense of belonging: 'I belong to the Jews. Not because I was born one or because I share their faith - I never have done. I belong to the Jews because I have suffered as one of them. It's suffering that has made me Jewish. I belong to people who have been murdered or who are still struggling to escape death' (Bauman, 1986:181). One might speculate that it was the reading of Janina's experiences during the Holocaust that inspired Zygmunt to write Modernity and the Holocaust. He acknowledged the impact her book had upon his own thought: 'Having read Janina's book, I began to think just how much I did not know - or rather, did not think about properly. It dawned on me that I did not really understand what had happened in that 'world which was not mine"' (Bauman, 1989:vii). Janina survived the concentration camps, and Zygmunt himself had escaped the persecution of the Jews during the war as he was stationed as a Polish solider in Russia. But the experiences of the Jews still became an important prism for his critical analysis of the suffering caused by the industrialized and organized killing of millions of people. In Modernity and the Holocaust Bauman thus outlined the social processes making the Holocaust possible and also the social processes that made it possible to exempt 
oneself from responsibility for the atrocities and suffering imposed on the Jews. The Holocaust was indeed an extreme (yet not entirely exceptional) example of socially imposed suffering (Langer, 1996), but it was nevertheless in many ways symptomatic (Bauman calls it a 'byproduct') of the way modern society sought to solve its problems with deviance, difference and ambivalence: to remove it from the face of the earth through dehumanization, stigmatization, incarceration or annihilation. Even though the fate of the Jews was only one extreme example of solid-modern suffering, it was caused by the same mechanisms and strategies also employed in less extreme situations and with less atrocious outcomes.

In Bauman's view, there are thus several driving forces behind the Holocaust and solidmodern suffering, some of which can be boiled down to individual brutalism and sadism, ideological indoctrination, blind obedience to authority and culturally constructed stereotypes of the victims. However, also other seemingly more 'innocent' social causes and processes were involved such as what he terms 'adiaphorization' - meaning the emptying of action of moral content. According to Bauman, adiaphorization exists as a three-legged phenomenon: (1) by the articulation of action into the hierarchy of command and execution thereby placing actors in an 'agentic state' (Stanley Milgram's (1974) term) in which their actions, however horrific, are not evaluated according to standards of individual conscience or moral indignation; (2) by 'effacing the face' of the victim, which consists of casting the objects of action into a position in which they are not regarded as worthy or deserving of moral considerations and thus evicting them from the class of beings for whom we should feel morally responsible; and (3) by destroying the object of action as a self and reducing it to a collection of separate parts or attributes whereby the total moral subjectivity of the individual or groups of individuals towards whom action is taken is utterly denounced and denied (see, e.g. Bauman, 1995:148-152). Obviously, solid modernity was not all about mass murder and human suffering, but Bauman's point is that many important traits of modernity made the very scope, effectiveness and denial of these inhumanities possible.

Bauman concluded Modernity and the Holocaust with a critique of what he called 'Durksonianism' (a neologism constructed by combing the surnames of Émile Durkheim and Talcott Parsons) and functionalist explanations of the social/societal grounds of moral behaviour claiming that 'society is the cure for the wolf in man' (Beilharz, 2000:42), which - seen in the light of the Holocaust - were unable to explain the inhumane atrocities as well as those who refused to follow suit and instead helped the victims. Moreover, in the Appendix to the book Bauman outlined the contours of a postmodern theory or morality to which we shall return later. 


\section{Liquid-modern suffering}

At the threshold of the new millennium, Bauman published a book that would significantly define and shape the subsequent writings until his death in 2017. That book was Liquid Modernity (2000a). The book - and the string of titles published in its slipstream - all used the metaphor of 'liquid modernity' to capture contemporary society. It was Bauman's contention that the concept of 'postmodernity', which he had preferred throughout the 1990s, had now served its purpose by paving the way and clearing the ground for this new notion that signalled (together with its concomitant notion of 'solid modernity') how something substantial had happened to the world, which required a new vocabulary. Whereas 'solid modernity', as we saw above, was conceptualized as a time of nation states, heavy capitalism and an industrialization of genocide, 'liquid modernity' is rather a time marked by a dissolution of the solids of the past (states, collective identities, communities, relationships and so on), meaning that they are unable to hold their shape for long. Moreover, it inaugurates a time when deregulation, marketization, privatization and a separation of power and politics making the latter impotent in dealing with the problems faced by society (Bauman, 2007). This 'liquidization' process impacts all dimensions of society from the macro-global level to the most intimate aspects of human life. It also impacts the way suffering is experienced, expressed, distributed and managed.

Whereas the suffering associated with solid-modern society according to Bauman was often the outcome of totalitarian tendencies inherent in modernity, in liquid-modern society suffering is much more dispersed, mediated and intangible. As he in the beginning of the new millennium stated on this transition from solid-modern to liquid-modern violence and the suffering resulting from it:

A century likely to go down in history as one of violence perpetrated by nation-states on its subjects has come to a close. Another violent century - this time a century of violence prompted by the progressive disablement of the nation-states by free-floating global powers - is likely to succeed it (Bauman, 2001a:219).

This transition does not mean, however, that the suffering caused by totalitarianism, nationalism and state-sponsored violence (symbolic or actual) has disappeared, but it has increasingly been supplemented by a plethora of largely invisible social forces leading to new forms of suffering - some of which are difficult to detect and document, but they are nevertheless experienced as suffering. This is the suffering that is the outcome of large-scale social processes such as 
individualization, marketization and globalization (and a concomitant retreat of state powers and a dismantling of the welfare state). In Bauman's perspective, we therefore need to reorient the focus of sociological analysis towards these new roots and expressions of suffering and social injustice. Whereas Jürgen Habermas (1984) had famously suggested that we need to pay critical attention to the incessant colonization of the lifeworld by the system, Bauman instead proposes that we in liquid-modern times need to look carefully at how the public sphere is increasingly colonized by private interests:

The task of critical theory has been reversed. That task used to be the defence of private autonomy from the advancing troops of the 'public sphere', smarting under the oppressive rule of the omnipotent impersonal state and its many bureaucratic tentacles or their smaller-scale replicas. The task is now to defend the vanishing public realm, or rather to refurnish and repopulate the public space fast emptying ... It is no more true that the 'public' is set on colonizing the 'private'. The opposite is the case: it is the private that colonizes the public sphere (Bauman, 2000:39).

Thus, according to Bauman the suffering experienced (and the violence in liquid-modern society no longer primarily stems from bureaucratic or totalitarian repression or industrially organized mass murder but also - and perhaps more so than previously - from the pitfalls of a shrinking and increasingly militarized public sphere, from the pains associated with individualization, from the failures of successful consumerism and from the relentless and uncontrollable forces of globalization creating 'collateral damages' on all levels of social life.

Throughout his writings in the new millennium, Bauman thus identifies several engines of liquid-modern suffering and he labelled individualization and globalization the two 'metacauses' of suffering. The title of his book Globalization - The Human Consequences (1998a) almost says it all: there are winners but also losers of the globalization game. The winners are the 'tourists' who can enjoy all the freedoms and opportunities available to them and who are welcomed with open arms everywhere, whereas the 'vagabonds' are the losers who remain on the move out of need and who are welcomed nowhere (perhaps a fitting metaphor for many of the refugees and migrants). It is Bauman's point that mobility - its causes and outcomes - is one of the greatest stratifying factors of contemporary society. Moreover, as Bauman described 
in detail in The Individualized Society (2001a), in times of individualization one is increasingly individually responsible for one's successes but also for one's own suffering. There is no more salvation from society - the winners can pride themselves of their successes, whereas the losers will have to bear their failures in shameful solitude (Bauman, 2001a). As a consequence, previously popular notions of a 'collective fate' - of the working-class or the Jews - no longer make sense in the same way as they did a century ago (even though Bauman does recognize the increasingly utilized notion of the 'precariat'). As Bauman asserted: 'Present-day miseries are not synchronized; to each door catastrophe knocks selectively, on different days, at different hours ... Our sufferings divide and isolate: our miseries set us apart, tearing up the delicate tissue of human solidarities' (Bauman, 1999a:53-54). This does not mean, however, that 'collective fates' have necessarily disappeared (just think of the many groups still persecuted collectively around the world), but it does suggest that at least in a Western context the process of individualization has gradually shifted the focus from collectives to individuals. Previously, in Bauman's view, hardships and defeats were suffered collectively, and the responsibility for relieving suffering was placed on the strong shoulders of collective charity, social solidarity and the welfare state. Now, private insurance schemes and a gradual winding down of the welfare system make the motto 'every man for himself' the mantra of our times. In liquid modernity, there are no 'joining forces', no 'us', no 'standing arm in arm', no 'mutual responsibility' - everything in the last instance falls back upon the increasingly isolated and vulnerable individual. As Bauman observes, 'in our 'society of individuals' all the messes into which one can get are assumed to be self-made and all the hot water into which one can fall is proclaimed to have been boiled by the hapless failures who have fallen into it' (Bauman, 2001a:9). No sympathy, no solidarity, no shared responsibility, only individual shame, self-recrimination and guilt. In a liquid-modern society of apparently 'self-made' men and women, there is no more any salvation to be expected from society. It is your mess and your problem, so stop blaming somebody else or society! Divided we stand, and divided we fall. The fate of the so-called 'human waste' (Bauman, 2004) and of those living in the 'involuntary ghettos' (Bauman, $2001 b$ ) is no longer a common concern.

Moreover, in recent times we have also witnessed the transformation from a society of producers to a society of consumers. Nowadays individual identity according to Bauman is mainly constructed around the image of the consumer and society simultaneously engages with and interpellates its members as consumes (Bauman, 2000a:76, 2007). Obviously, there has always been poor people - those unable to earn a living and those outside of the labour market forced to live off the 'benefits' provided by others. However, in a society of consumers or a 
consumer society, the losers are now those excluded from consuming. They are not only barred from contributing to production and from making a living, but adding insult to injury they are also excluded from participation in the game of consumption. They are what Bauman (1998b) calls 'flawed consumers' and being such a flawed consumer is regarded as one's own fault due to laziness, lack of effort or simply bad luck: 'Being excluded is presented as an outcome of social suicide, not a social execution' (Bauman, 2000b:207). In Bauman's view, in liquidmodern society primarily two strategies are employed in order to deal with the poor, global as well as local, or at least to make their misery unmistakably their own fault. First, the 'criminalization of poverty', and second, the 'brutalization of the poor'. Both strategies consist of policing and incarcerating the poor, cutting their welfare benefits to a bare minimum, and by presenting their suffering as self-inflicted misfortune. Bauman wonders: 'Under such conditions, one would expect a widespread feeling of injustice, with a potential to condense into a mass protest movement, if not an open rebellion against the system. The fact that this does not happen testifies perhaps to the effectiveness of the combined strategies of exclusion, criminalization, and brutalization of potentially 'problematic' strata' (Bauman, 1997b:235). Consumerism's cutthroat competition, self-blame and mutual estrangement has replaced cooperation, collective responsibility and solidarity (with tolerance, as mentioned, squeezing solidarity to the side), thus leaving the suffering to their own misfortune.

As is evident from this condensed extract from some of Bauman's 'liquid-modern writings', many of the causes of suffering in contemporary society remain blurred, amorphous or abstract. Moreover, the human experiences of suffering are often hidden from plain sight tucked away in ghettos, refugee camps or other sites with little or no public interest. It is important to stress that adiaphorization has thus not disappeared - it was not only part of the bureaucracy and technology of solid-modern times. Bauman mentions how adiaphorization today expands primarily through processes of 'insensitivitization' via the constant exposure to suffering and cruelty on the media and the 'distanciation' between the actions of the perpetrators of cruelty and their victims due to technological advances (Bauman, 1995:148-152). In this way, a lot of the suffering in liquid modernity remains as invisible and unnoticed as it is routinely ignored.

\section{Is there a cure for suffering?}

People have suffered throughout thousands of years. But the way suffering is caused and experienced seems to have changed. In Bauman's work, suffering is primarily treated as a social 
phenomenon, although it may be individually experienced. Suffering is a human emotional response to different experiences of degradation, harm, pain, maltreatment, marginalization and so on. Obviously, the above separation between solid-modern and liquid-modern sources and causes of suffering does not really make sense. Only analytically can we claim that some causes of suffering are more solid than liquid. Bauman's shift in orientation towards the processes of globalization, individualization and consumerism therefore does not signal that these causes of suffering have replaced previous ones, but it is his way of showing - and perhaps today more than before - that suffering can also be the outcome of seemingly 'innocent' social processes. The adiaphorizing engine set in motion in the mass murder of the Jews - aided and abetted by modern bureaucracy and technology - is still with us today and is at work in ethnic cleansings or war atrocities around the world (think, for example, of the displacement and murder of the Rohingya people in Myanmar). It remains a latent source of suffering. But whereas the suffering experienced in solid modernity was often associated with state-sponsored violence and brutality and totalitarian means of coercion and oppression, in liquid modernity there is often no immediately identifiable perpetrator or culprit of the evil that happens to people, just anonymous forces of capitalist deregulation and privatization of every aspect of human life. This apparent invisibility of the sources of suffering may mislead us to thinking that the causes of suffering almost become amorphous and that there is no responsibility involved. Even though Bauman is not searching for someone to blame, he insists that the causes of suffering are social and therefore not inevitable or immune to intervention. In Bauman's work, there is thus no interest in natural suffering - a suffering that has its roots in natural conditions of human life. The suffering that concerns him is always caused by and is experienced in social circumstances. There is nothing natural about inequality, evil or persecution in his work. It is created and perpetuated by social arrangements or structural conditions and the outcome is, for example, genocide, unemployment, poverty, marginalization, deprivation and so on.

Hence, can something be done to alleviate suffering? Although there is no doubt about Bauman's ambition to annihilate suffering, besides occasionally arguing for 'basic income' he remains silent when it comes to spelling out specific strategies or policies that may be put to use. One might perhaps suspect that the best way to minimize or eliminate social suffering would be resorting to social mechanisms and solutions. However, this is not Bauman's position - or at least not the primary one. Bauman's position - developed throughout several books from the early $1990 \mathrm{~s}$ - is that we cannot meaningfully legislate about morality, and the problem and persistence of suffering is fundamentally a moral matter. In his view, even though he acknowledges the importance of strong social and global institutions, the creation and perpetuation of 
suffering is ultimately a matter of personal responsibility. Morality is a pre-social impulse - it does not stem from society but from the moral individual. Morality is, for all practical intents and purposes, not suited for legislative initiatives or formalized procedures. As he stated, leaning heavily on the philosophical ideas of Emmanuel Levinas and K. E. Løgstrup: '[T] he greater the moral responsibility, the dimmer is the hope of its normative regulation' (Bauman, $1998 \mathrm{c}: 20$, original italics). The truly moral self, in Bauman's view, is constantly haunted by the gnawing suspicion that he/she is not moral enough and that more could have been done to alleviate the suffering of others (Bauman, 1993:80). We cannot claim to be moral beings without recognizing and embracing - however painful, inconvenient, unrewarding or time-consuming - the moral responsibility for the well-being of the sufferers. Morality is not about reason or rationality. Our genuine moral commitment cannot be decided on pious desires or idle daydreams, but only on our willingness to practice what we preach. If morality remains a matter of pure thought or inner conversation, then it will not suffice. The Good Samaritan was good not because of what he contemplated doing, but due to what he actually did - intervening in the suffering and taking care of the need of an absolute stranger. To turn our backs, to refrain from intervening or protesting, amounts to accepting that there are structures and processes in the world that perpetuate inhumanity and create suffering. Throughout his work, Bauman insisted that we need to orient ourselves to the reality of suffering and to actively pursue the alleviation of suffering. As he stated:

The price of silence is paid in the hard currency of human suffering. Asking the right questions makes, after all, all the difference between fate and destination, drifting and travelling. Questioning the ostensibly unquestionable premises of our way of life is arguably the most urgent of the services we owe our fellow humans and ourselves (Bauman, 1998a:5).

Unquestionably, there is something utterly utopian about Bauman's moral stance (that our individual moral responsibility will suffice, that we can help everyone, and that we are willing to go very far to do so). Bauman was fully aware that we cannot care equally for everybody in the world - there are limits to whom we can care for. He thus proposed that there are certain 'victims of suffering' towards whom our concern should particularly be directed - this is the 
suffering of those who are defenceless and unable to demand our sympathy and solidarity. As he once stated about those who most need not only our moral concern but also our moral action:

The children, bodily too weak to resist physical force and mentally too inarticulate to oppose, or even ask for, an argument and a proof; the animals, devoid of language in which the demand could be phrased and of the skills to solicit rights by bargaining or coercion; the yet unborn single beings or generations of beings, unable to address us, to reciprocate or retaliate, even to appear to us as Faces, as bearers of needs and givers of demands; the poor and indolent, the deprived and the dispossessed, denied human rights by the Law, convention or custom, or too feeble to execute such rights as have been formally awarded to them ... These are the cases of moral responsibility reaching its peak (Bauman, 1998c:20).

These groups - children, generations of the yet unborn, animals, the social outcasts and the weak - epitomizes the suffering Other, whose plight we are particularly responsible for relieving. It is Bauman's position that the weaker the Other, the more the burden of responsibility weighs upon our shoulders.

Bauman's understanding of morality (and with it the answer to the problem of suffering) is thus mainly in opposition to what might be called the Hobbesian answer to the problem of order - that of instituting a moral and social order that pre-empts its members' freedom of choice. Bauman is opposed to an anarchic state of nature (such as the one found in contemporary consumerism) inhabited by the homo lupus - man as a wolf - in which everybody wants to have their cake and eat it. Bauman, however, is also opposed to the bureaucratic ethos as well as business ethics, any type of organizational contraption that either forces or seduces people into acting in ways at odds with their unconditional moral responsibility for the wellbeing of others and which results in a 'free-floating responsibility' (see, e.g., Kaulingkreks, 2005). For Bauman, our responsibility is personal. For example, to him it does not matter how many people opposed the suffering and killing of the Jews during World War II but that some did (Bauman, 1989:207). Solidarity and morality, like suffering, is not a matter of quantity, but of quality - of the suffering and the actions taken to prevent it. His answer, no matter how unrealistic and unpersuasive it may seem, is thus a 'morality without ethics'- a human form of moral responsibility not regulated by externally enforced rules and societally induced norms 
(as in a functionalist view of the world), but by an innate sense of responsibility and solidarity. Bauman's moral stance is that of a 'morality of choice' rather than a 'morality of conformity' (Bauman, 1998c) - if morality is forced through, it stops being 'morality' and turns into 'ethics'.

Bauman is painfully aware that this 'morality of proximity', as he also calls it, cannot stand alone. He recognizes the almost insurmountable obstacles to the realization of such a micro-moral stance in a world ruled by forces of globalization, individualization and consumerism (see Bauman, 1997b, 1999b). In times marked by such global challenges, morality more than ever before needs the backing of large-scale initiatives and requires more solid levers than just individual conscience and responsibility. As he once noted: 'Morality which always guided us and still guide us today has powerful, but short hands. It now needs very, very long hands indeed' (Bauman, 1993:218). Without being coupled with political intervention of a more extensive reach, such a localized/personalized morality will prove impotent in dealing with and suffering on a global scale. As mentioned, in Bauman's view there is nothing natural or inevitable about other people's suffering - it can be prevented. It requires awareness and willingness to act. In our increasingly globalized world, however, these two dimensions are often found missing. Politics and power have been separated, and the suffering we witness is often 'distant suffering' that we find difficult to relate to (Boltanski, 1999). It also means the willingness not least within Bauman's often academic readership - to nurture an awareness of how suffering is a structurally created and maintained phenomenon.

As should be evident from the above, Bauman's work is unmistakably moral in that it respects the reader and yet calls upon the him/her to respect the text and, also, understand the circumstances of her or his own being in the world. In that way, the reader will see that his/her own personal situation is intimately linked to wider public issues and, thereby, sociology will have engaged in its specific action of enlightenment. Richard Sennett once mentioned this moral dimension of Bauman's work, by saying that Bauman speaks to the present because 'he suggests that there is a real realm to navigate of personal responsibility, and that makes contact with young people ... It really appeals when someone tells them that they're responsible for relating to others in an ethical way. That's why he is so popular' (Sennett in Bunting, 2003:20).

\section{Conclusion}

This article has presented and discussed the perspective on suffering as developed by Zygmunt Bauman throughout his extensive body of work. It has been shown how the theme of suffering has continued to constitute an important leitmotif in his concern with understanding the social 
world. As should be evident from the above, Bauman always sides with those who are suffering, no matter whether their suffering is spectacular or invisible, publicly recognized or silenced. Bauman's sociology presents us with a distinctly qualitative look into the diversified world of social suffering. His work on suffering - social inequality, violence, mass murder, marginalization and so on - does not rest on statistical refinery or measurements. Although he does at times quote some official statistics, most of his ideas on suffering are of a theoretical nature, relying primarily on insights from philosophers, social theorists and his own unique analytical template.

We have also seen how the specific focus on suffering has changed throughout his work: from a focus specifically on the working-class, then later the Jews to a more generalized perspective of the different faces of liquid-modern suffering. It seems as if there has been a change from concreteness to abstractness in his treatment of suffering - in its causes and in its experiences. This not least pertains to the increasing invisibility or blurring of the liquid-modern causes of suffering. Of course, corporate (or casino) capitalism, neoliberal deregulation and consumerism can rightly be blamed (see, e.g. Giroux, 2011), but today it is seemingly far more difficult to single out identifiable culprits responsible for the production, proliferation and perpetuation of suffering than it was with many of the solid-modern predecessors. Bauman's work thus raises the question: Who are the suffering really? Who are these outcasts, strangers, wasted lives, human weeds, new poor, the underclass, lives unworthy of life and whatever else Bauman throughout his work has called the groups of sufferers? Are they the refugees in the asylum centres, the recipients of social benefits, the homeless, the sexually deviant and persecuted, the starving in the developing countries, the unemployed, ethnic minorities, or perhaps all of the above? For better or for worse, Bauman only rarely (besides in his work on the Jews in the concentration camps) specifies the sufferers and they therefore often remain strangely nameless and faceless in his work. Moreover, perhaps Bauman even overlooks some sorts of suffering. At least according to Ali Rattansi (2017), Bauman throughout his work neglected topics such as race, imperialism and gender in his analyses. This also means that Bauman is somewhat blind to the suffering related to these specific areas. Moreover, although Bauman's work is generally characterized by a global outlook, many examples from non-Western contexts might in fact challenge or even refute some of his claims, e.g. on the importance of processes of individualization or consumerism on contemporary experiences of suffering.

In his work, Bauman outlined, as we saw, some of the moral implications of the persistence of suffering. In his view, we should all be outraged at the knowledge and sight of suffering and spurred into action. However, it is his contention that we have become increasingly blind 
or immune to the suffering of others in liquid-modern society (Bauman and Donskis 2013). Whereas people living in solid-modern society could conjure up excuses that they did not know what was going on (e.g. to the Jews in the concentration camps) in order to sooth their conscience, nowadays such an excuse is as hollow as it is untrue. Most of us - not least due to the network of information technologies now available - know about and sometimes even witness atrocities as they unfold. We are no longer capable of shrouding our inaction with lack of knowledge, innocence and non-complicity. Bauman thus uses his writings as a clarion call to his readers to take on their responsibility, and although 'Bauman's voice is often friendly ... it is uncompromising in the demands that it makes upon the reader as reader and as ethical actor' (Beilharz, 2001:3). Bauman demands of his readers that they not only recognize the reality of suffering but that they armed with this knowledge will also accept the responsibility that follows from this knowledge. Bauman's sociology is thus a normative endeavour - aimed at pointing to the many inequalities, injustices and inhumanities of social life - and asking us to make a difference.

In summary, Zygmunt Bauman in his writings provides us with a sociology of the underdog, the outcast, the downtrodden and the sufferers. His sociology, however, is not a defeatist declaration that we must passively accept this situation. Suffering is real, and killing it by its roots may seem utopian, but Bauman was and remained a utopian of sorts. We can do something about suffering. Despite this claim, he almost always steered clear of providing concrete solutions, prophylaxes or recipes for action (besides his defence for a basic income), the danger lurking of closing down options rather than opening reality up to human intervention and transformation. We should therefore always keep our eyes open for the unused possibilities, the uncovered terrains, the unchartered territory. Bauman continuously insisted that the world can be made into a better - more just, more free, more humane - place, but that it is up to us to decide to do something about it and to act upon our conscience and moral responsibility - it cannot be legislated or forced through. As Keith Tester once admirably pointed out about Bauman's work: 'Within his sociology, Bauman tries to show that the world does not have to be the way it is and that there is an alternative to what presently seems to be so natural, so obvious, so inevitable' (Tester in Bauman and Tester, 2001:9). Bauman's sociology is thus an uncompromising all-out attack on any assumptions about the world as readymade or unchangeable. The suffering in the world cannot simply be wished or analyzed away, it needs to be countered and challenged, and sociology plays an important role in this. As Bauman thus stated in his inaugural lecture in Leeds in 1972: '[E]ither sociology will make sense of the human world, 
thereby living power to the powerless, or it must admit its own powerlessness to make sense of its own existence' (Bauman, 1972:186).

\section{References}

Bauman, Janina (1986): Winter in the Morning. London: Virago.

Bauman, Zygmunt (1972): 'Culture, Values and Science of Society'. University of Leeds Review, 15 (2):185-203.

Bauman, Zygmunt (1976a): Socialism - The Active Utopia. London: Hutchinson.

Bauman, Zygmunt (1976b): Towards a Critical Sociology - An Essay on Common Sense and Emancipation. London: Routledge and Kegan Paul.

Bauman, Zygmunt (1978): Hermeneutics and Social Science - Approaches to Understanding. London: Hutchinson.

Bauman, Zygmunt (1982): Memories of Class: The Pre-History and After-Life of Class. London: Routledge \& Kegan Paul.

Bauman, Zygmunt (1987): Legislators and Interpreters - On Modernity, Post-Modernity and Intellectuals. Cambridge: Polity Press.

Bauman, Zygmunt (1988): Freedom. Buckingham: Open University Press.

Bauman, Zygmunt (1989): Modernity and the Holocaust. Cambridge: Polity Press.

Bauman, Zygmunt (1990): 'From Pillars to Post'. Marxism Today, February, pp. 20-25.

Bauman, Zygmunt (1991a): Modernity and Ambivalence. Cambridge: Polity Press.

Bauman, Zygmunt (1991b): 'Postmodernity: Chance or Menace?'. Occasional Papers, 2. Centre for the Study of Cultural Values, Lancaster University.

Bauman, Zygmunt (1992): Intimations of Postmodernity. London: Routledge.

Bauman, Zygmunt (1993): Postmodern Ethics. Oxford: Blackwell.

Bauman, Zygmunt (1995): Life in Fragments. Oxford: Blackwell.

Bauman, Zygmunt (1997a): Postmodernity and Its Discontents. Cambridge: Polity Press.

Bauman, Zygmunt (1997b): 'Morality Begins at Home - Or: Can There Be a Levinasian MacroEthics?', in Harald Jodalen and Arne Johan Vetlesen (eds.): Closeness - An Ethics. Oslo: Scandinavian University Press, pp. 218-245.

Bauman, Zygmunt (1998a): Globalization - The Human Consequences. Cambridge: Polity Press.

Bauman, Zygmunt (1998b): Work, Consumerism and the New Poor. Buckingham: Open University Press. 
Bauman, Zygmunt (1998c): 'What Prospects of Morality in Times of Uncertainty?'. Theory, Culture and Society, 15 (1):11-22.

Bauman, Zygmunt (1999a): In Search of Politics. Cambridge: Polity Press.

Bauman, Zygmunt (1999b): 'The World Inhospitable to Levinas'. Philosophy Today, 43 (2):151-167.

Bauman, Zygmunt (2000a): Liquid Modernity. Cambridge: Polity Press.

Bauman, Zygmunt (2000b): 'Social Uses of Law and Order'. British Journal of Criminology, 40 (2):205-221.

Bauman, Zygmunt (2001a): The Individualized Society. Cambridge: Polity Press.

Bauman, Zygmunt (2001b): Community - Seeking Safety in an Insecure World. Cambridge: Polity Press.

Bauman, Zygmunt (2004): Wasted Lives: Modernity and its Outcasts. Oxford: Polity Press.

Bauman, Zygmunt (2007): Consuming Life. Cambridge: Polity Press.

Bauman, Zygmunt (2011): Collateral Damage - Social Inequalities in a Global Age. Cambridge: Polity Press.

Bauman, Zygmunt (2013): Does the Richness of the Few Benefit Us All? Cambridge: Polity Press.

Bauman, Zygmunt (2016): Strangers at Our Doors. Cambridge: Polity Press.

Bauman, Zygmunt and Keith Tester (2001): Conversations with Zygmunt Bauman. Cambridge: Polity Press.

Bauman, Zygmunt and Leonidas Donskis (2013): Moral Blindness - The Loss of Sensitivity in Liquid Modernity. Cambridge: Polity Press.

Beilharz, Peter (2000): Zygmunt Bauman - Dialectic of Modernity. London: Sage Publications.

Beilharz, Peter (ed.) (2001): The Bauman Reader. Oxford: Blackwell.

Bericat, Eduardo (2016): 'The Sociology of Emotions: Four Decades of Progress'. Current Sociology, 64 (3):491-513.

Best, Shaun (2016): 'Zygmunt Bauman: On What It Means to be Included'. Power \& Education, 8 (2):124-139.

Boltanski, Luc (1999): Distant Suffering: Morality, Media and Politics. Cambridge: Cambridge University Press.

Bourdieu, Pierre et al. (1999): The Weight of the World: Social Suffering in Contemporary Society. Stanford, CA: Stanford University Press. 
Bunting, Madeline (2003): 'Zygmunt Bauman: Passion and Pessimism'. The Guardian, April 4:20-23.

Carleheden, Mikael (2008): 'Bauman on Politics - Stillborn Democracy', in Michael Hviid Jacobsen and Poul Poder (eds.): The Sociology of Zygmunt Bauman - Challenges and Critique. Farnham: Ashgate Publishing, pp. 175-192.

Giroux, Henry A. (2011): 'Neoliberalism and the Death of the Social State: Remembering Walter Benjamin's Angel of History'. Social Identities, 17 (4):587-601.

Habermas, Jürgen (1984): The Theory of Communicative Action. Boston: Beacon Press.

Hochschild, Arlie R. (1990): 'Ideology and Emotion Management: A Perspective and Path for Future Research', in Theodore D. Kemper (ed.): Research Agendas in the Sociology of Emotions. Albany, NY: State University of New York Press, pp. 117-142.

Jacobsen, Michael Hviid (2019): 'Liquid-Modern Emotions: Exploring Zygmunt Bauman's Contribution to the Sociology of Emotions'. Emotions and Society, 1 (1):99-116.

Jacobsen, Michael Hviid (2020): 'Evil-by-Proxy and Everyday Monsters - Toward a Moral Sociology for Overcoming the Passive Observation of Evil', in Caroline Joan S. Picart (ed.): Monsters, Law, Crime: Explorations in Gothic Criminology. Lanham, MD: Rowman \& Littlefield, pp. 97-119.

Jacobsen, Michael Hviid and Sophia Marshman (2008): 'The Four Faces of Human Suffering in the Sociology of Zygmunt Bauman - Continuity and Change'. Polish Sociological Review, $1(161): 3-24$.

Kaulingfreks, Ruud (2005): ‘Are We All Good? Zygmunt Bauman's Response to Hobbes'. The Sociological Review, 53 (1):30-45.

Kleinman, Arthus, Veena Das and Margaret Lock (1996): 'Introduction'. Daedalus (Special Issue on Social Suffering), 125 (1):xi-xx.

Langer, Lawrence L. (1996): 'The Alarmed Vision: Social Suffering and Holocaust Atrocity'. Daedalus (Special Issue on Social Suffering), 125 (1):47-65.

Milgran, Stanley (1974): Obedience to Authority: An Experimental View. New York: Harper \& Row.

Mills, C. Wright (1959): The Sociological Imagination. New York: Oxford University Press. Permebrton, Simon (2016): Harmful Societies - Understanding Social Harm. Bristol: Policy Press. 
Rattansi, Ali (2017): 'Race, Imperialism and Gender in Zygmunt Bauman's Sociology - Partial Absences, Serious Consequences', in Michael Hviid Jacobsen (ed.): Beyond Bauman Critical Engagements and Creative Excursions. London: Routledge, pp. 65-85.

Smith, Dennis (1998): 'Zygmunt Bauman - How to Be a Successful Outsider'. Theory, Culture and Society, 15 (1):39-45.

Tester, Keith (2004): The Social Thought of Zygmunt Bauman. London: Palgrave/Macmillan.

Wilkinson, Iain (2004): 'The Problem of 'Social Suffering': The Challenge to Social Science'. Health Sociology Review, 13 (2):113-121.

Wilkinson, Iain (2005): Suffering: A Sociological Introduction. Cambridge: Polity Press.

Wilkinson, Iain (2007): ‘On Bauman's Sociology of Suffering: Questions for Thinking’, in Anthony Elliott (ed.): The Contemporary Bauman. London: Routledge, pp. 241-256.

\section{About the Author:}

Michael Hviid Jacobsen is Professor of Sociology at the Department of Sociology and Social Work, Aalborg University, Denmark. His research interests cover: social theory, the sociology om emotions, criminology, qualitative research methods, death, dying, grief and immortality. 